\title{
THICK EPITAXIAL GaAsBi LAYERS FOR TERAHERTZ COMPONENTS: THE ROLE OF GROWTH CONDITIONS
}

\author{
S. Stanionytė ${ }^{\text {a }}$ A. Vailionis ${ }^{\text {b }}$, V. Bukauskas ${ }^{\text {a }}$, S. Tumènas ${ }^{\text {a }}$, A. Bičiūnas ${ }^{\text {a }}$, A. Arlauskas a, \\ R. Butkutè ${ }^{a}$, and A. Krotkus ${ }^{\text {a }}$ \\ ${ }^{2}$ Department of Optoelectronics, Center for Physical Sciences and Technology, Sauletekio 3, Vilnius, Lithuania \\ ${ }^{\mathrm{b}}$ Geballe Laboratory for Advanced Materials, Stanford University, McCullough Bldg. 126A, CA94305, USA \\ Email: renata.butkute@ftmc.lt
}

Received 28 February 2018; accepted 22 March 2018

\begin{abstract}
A series of $1.5 \mu \mathrm{m}$-thick epitaxial GaAsBi layers have been grown by molecular beam epitaxy on semi-insulating $\operatorname{GaAs}(100)$ substrates at temperatures ranging from 300 to $370^{\circ} \mathrm{C}$. Complex studies were carried out with a focus to optimize the technological parameters for application of these layers in photoconductive THz components. The investigation of crystalline structure, layer morphology, optical properties, and characteristics of carrier dynamics was performed. Up to $12 \%$ of Bi incorporation has been confirmed by optical and structural analyses of GaAsBi layers grown at relatively low temperatures of about $300^{\circ} \mathrm{C}$. The carrier lifetimes of these layers varied from 1 to 3 ps. Thick GaAsBi layers grown at higher than $350^{\circ} \mathrm{C}$ temperatures exhibited higher crystalline quality and longer carrier lifetimes reaching even tens of picoseconds. The Bi content in high-temperature-grown GaAsBi varied from 3 to $7 \%$ Bi.

Keywords: molecular beam epitaxy, GaAsBi, high resolution X-ray diffraction, atomic force microscopy, photoluminescence, $\mathrm{THz}$ spectroscopy
\end{abstract}

PACS: $81.15 \mathrm{Hi}, 61.10 . \mathrm{Nz}, 78.55 . \mathrm{Cr}, 68.37 . \mathrm{Ps}, 81.07 . \mathrm{St}$

\section{Introduction}

In the last decade a lot of attention has been paid to the development of $\mathrm{THz}$ photoconductors sensitive to wavelengths in the spectral range from 1 to $1.5 \mu \mathrm{m}$, because of the availability of more compact than the Ti-sapphire laser solid-state and fibre lasers operating in this spectral range [1]. The most popular material for photoconductive $\mathrm{THz}$ components is the so-called low-temperature-grown (LTG) epitaxial GaAs. Usually, these layers are deposited using molecular beam epitaxy (MBE) at substrate temperatures of about $200^{\circ} \mathrm{C}[$ [2]. $\mathrm{THz}$ components manufactured from
LTG-GaAs are sensitive to $1 \mu \mathrm{m}$ wavelength radiation only if they are not annealed or annealed at lower than $420^{\circ} \mathrm{C}$ temperature [3], however the efficiency of these components is rather low.

In [4] LTG-GaAsBi layers have been successfully used for fabrication of photoconductive $\mathrm{THz}$ frequency range components sensitive to long wavelength laser excitation. This ternary compound is attractive due to its unique properties such as the huge energy bandgap reduction by introducing Bi atoms to the arsenic site in the GaAs lattice and low energy bandgap sensitivity to temperature variation. It is known that in $\mathrm{GaAs}_{1-x} \mathrm{Bi}_{x}$ with $x<0.4 \%$ of Bi the energy bandgap reduces 
by about $88 \mathrm{meV}$, for compounds containing a larger amount of Bi this effect is lower and the energy bandgap reduces by $65 \mathrm{meV} / \% \mathrm{Bi}$. It was predicted that the optical absorption edge of bismide becomes equal to $1 \mu \mathrm{m}$ when $x=0.06$, and introducing $10 \%$ Bi the $1.5 \mu \mathrm{m}$ wavelengths can be achieved [5]. Since Bi mainly affects the valence band states, the electron mobility in bismides is like in high-temperature-grown $\mathrm{GaAs}$ and exceeds $2000 \mathrm{~cm}^{2} / \mathrm{Vs}$ [ 6 ]. On the other hand, the electron mobility is significantly larger than in LTG-GaAs. Moreover, the electron trapping times in GaAsBi can be precisely manipulated by thermal annealing of the layers. In contrast to LTG-GaAs, for which thermal annealing results in the increase of the electron trapping times, annealing of bismides at $600^{\circ} \mathrm{C}$ and higher temperature leads to the reduction of trapping times to values shorter than 1 ps 讯. THz time-domainspectroscopy (TDS) systems using photoconductive components made of $\mathrm{GaAsBi}$ with $6 \% \mathrm{Bi}$ and activated by $\mathrm{Yb}: \mathrm{KGW}$ and $\mathrm{Yb}$-doped fibre lasers, both emitting at $1030 \mathrm{~nm}$ wavelength, were already demonstrated in [8, 9], respectively. However, the yield of devices was quite low due to the poor crystalline quality of LTG-GaAsBi. For manufacturing of these components the bismide layers were grown in a solid-state MBE reactor using an $\mathrm{As}_{4}$ molecular source. The structural characterization demonstrated inhomogeneous bismuth distribution. The surfaces of bismide layers were rough and had numerous $\mathrm{Bi}$ droplets on the top.

In this article we present a systematic study of GaAsBi technological conditions with a focus to apply these layers in photoconductive $\mathrm{THz}$ components. The complex characterization performed for the determination of the influence of technological parameters on thick GaAsBi layers crystalline structure, morphology, surface roughness, optical properties, and characteristics of carrier dynamics is described.

\section{Growth and structural characterization of thick GaAsBi layers}

The GaAsBi layers were grown using the solidsource molecular beam epitaxy (MBE) SVT-A technique equipped with conventional Knudsen effusion cells for metallic $\mathrm{Ga}$ and $\mathrm{Bi}$. To provide $\mathrm{As}_{2}$ dimers as well for a highly controlled arsenic flux supply, a two-temperature-zone valved-crack- ing source was used. The samples were deposited on semi-insulating GaAs substrates oriented in the (100) crystallographic plane. The substrate temperature was monitored by thermocouple readings with an accuracy of $1^{\circ} \mathrm{C}$. Beam equivalent pressures (BEP) of $\mathrm{Ga}, \mathrm{As}_{2}$, and $\mathrm{Bi}$ were measured with the retractable ion gage. The cleaning of wafers and growth was in situ monitored by the reflection high energy electron diffraction (RHEED) system. Prior to the growth the native oxide was removed at $630^{\circ} \mathrm{C}$ temperature supplying a maximum arsenic flux. For smoothing of the surface the GaAs buffer layer was grown under standard conditions: at substrate temperature of $600^{\circ} \mathrm{C}$ and at arsenic over-pressure with a considerable $\mathrm{As}_{2} / \mathrm{Ga}$ BEP ratio exceeding 10. The sufficient smoothing of the substrate was determined by the appearance of streaky reflexes of $(2 \times 4)$ surface reconstruction in a RHEED screen. The thickness of buffer layers varied from 100 to $200 \mathrm{~nm}$ for different samples. At high temperature and arsenic overpressure, Bi incorporation is negligible because bismuth atoms tend to segregate to the surface and act as surfactants. To enhance the Bi incorporation, growth temperatures as low as 300$400^{\circ} \mathrm{C}$ and $\mathrm{As}_{2} / \mathrm{Ga}$ pressure ratio close to 1 are used. Thus, after the buffer layer growth the process was interrupted for temperature reduction and stabilization of the BEP ratio $\mathrm{As}_{2} / \mathrm{Ga}$. The series of GaAsBi layers were grown at substrate temperatures ranging from 300 to $370^{\circ} \mathrm{C}$. The $(2 \times 1)$ surface reconstructions observed from the beginning to the end on the RHEED pattern for high temperature grown $\mathrm{GaAsBi}$ allowed us to assume that the epitaxial growth was accomplished in a layer-by-layer mode. The significant diminishing of the electron diffraction pattern registered for $\mathrm{GaAsBi}$ layers grown at lower substrate temperatures and higher bismuth fluxes suggested the $3 \mathrm{D}$ growth process. The $\mathrm{BEP}$ ratio of $\mathrm{As}_{2}$ and $\mathrm{Ga}$ varied from 1.033 to 1.090. In order to incorporate a larger bismuth content to the GaAs lattice, a metallic bismuth source was heated up to $500-540^{\circ} \mathrm{C}$ temperatures. The GaAsBi layer growth rate varied from 350 to $700 \mathrm{~nm} / \mathrm{h}$, and the thickness was $1500 \mathrm{~nm}$. The technological parameters of characteristic GaAsBi layers' growth are presented in Table 1.

The crystalline structure and surface morphology of samples were characterized by high resolution X-ray diffraction (HR-XRD) and atomic force microscopy (AFM) measurements, using 
Table 1. Main parameters of GaAsBi layers grown by MBE: $d$, thickness of layer; $T_{\mathrm{g}}$, growth temperature; $\mathrm{BEP}$, beam equivalent pressure ratio $\left(\mathrm{As}_{2} / \mathrm{Ga}\right) ; T_{\mathrm{Bi}}$, bismuth source temperature; $V$, growth rate of bismide layer; $\mathrm{Bi} \%$, bismuth content evaluated from X-ray diffraction measurements; $R m s$, surface roughness; $\tau$, carrier life times determined from teraherz spectroscopy of as-grown GaAsBi layer.

\begin{tabular}{c|c|c|c|c|c|c|c|c}
\hline Sample & $d, \mathrm{~nm}$ & $T_{\mathrm{g}}{ }^{\circ} \mathrm{C}$ & $\mathrm{BEP}(\mathrm{As} / \mathrm{Ga})$ & $T_{\mathrm{Bi}}{ }^{\circ} \mathrm{C}$ & $V, \mathrm{~nm} / \mathrm{h}$ & $\mathrm{Bi} \%(\mathrm{XRD})$ & $R m s, \mathrm{~nm}$ & $\tau, \mathrm{ps}$ \\
\hline B266 & 1500 & 300 & 1.033 & 534 & 675 & 12 & 6.1 & 1 \\
\hline B770 & 1500 & 350 & 1.085 & 520 & 350 & 7 & 0.7 & 16 \\
\hline B771 & 1500 & 370 & 1.088 & 500 & 500 & 3.3 & 0.5 & 38 \\
\hline
\end{tabular}

a SmartLab diffractometer (Rigaku, Japan) and a Dimension 3100 SPM system with a Nanoscope IVa controller (Veeco Instruments Inc., USA), respectively. The bismuth content in GaAsBi thick layers was evaluated from the measurements of rocking curves of the (004) reflex. The compressive strain relaxation was defined from reciprocal space maps (RSM) scanned for the (004) reflex and using grazing incident angle geometry for the (224) reflex. The AFM images were studied to evaluate the surface roughness of GaAsBi layers and to inspect the morphology in the case of metallic droplets.
The high resolution X-ray diffraction scan measured from (004) planes for the as-grown thick epitaxial GaAsBi layer (sample B266) is shown in Fig. 1 1(a). The main peak corresponds to the GaAs substrate, while the peak on the left is attributed to the epitaxial GaAsBi layer. The separation of these two peaks corresponds to the mismatch between the GaAsBi layer and GaAs substrate lattices. Dynamical simulations of XRD scans made by assuming the absence of tetragonal distortion were used for determination of the layer composition. Evaluating Bi content, the Vegard's law was assumed, and the value for the GaBi lattice

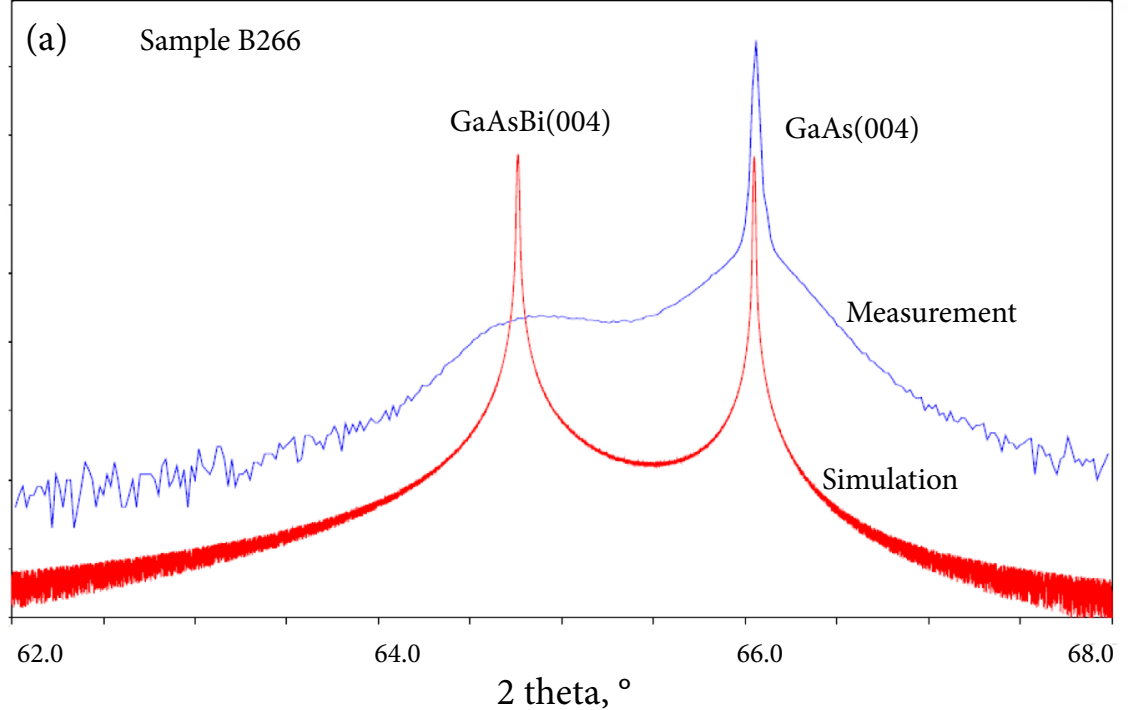

(b) (004)
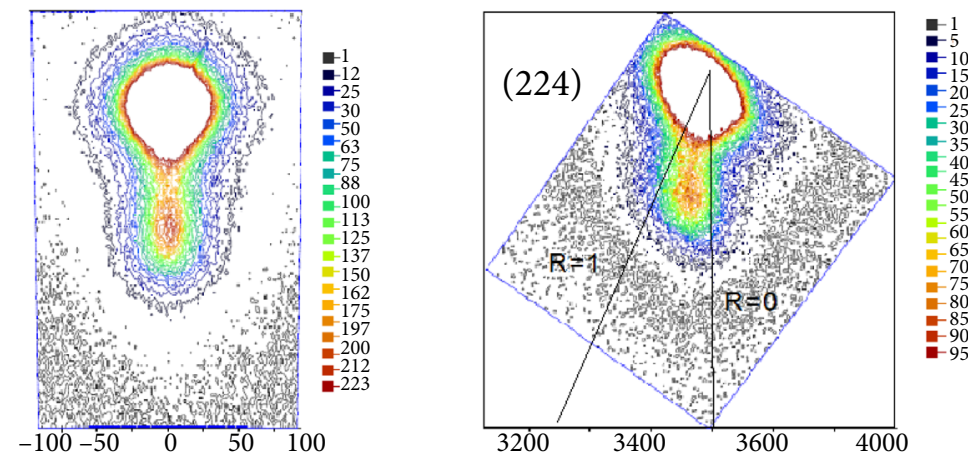

Fig. 1. High resolution X-ray diffraction scans of the 1500 nm-thick GaAsBi layer grown at $300^{\circ} \mathrm{C}$ temperature using the $\mathrm{BEP}$ ratio of $\mathrm{As} / \mathrm{Ga}-1.033$. (a) presents the $\omega-2 \Theta$ scan showing the curves of measurement (blue online) and simulation (red online), (b) demonstrates the reciprocal space maps for (004) reflex on the left and (224) reflex on the right. The colour (online) scales exhibit the intensity. To highlight the GaAsBi peak, the intensity of GaAs substrate (004) and (224) reflexes in RSM was zoomed in. $\mathrm{R}=0$ and $\mathrm{R}=1$ correspond to compressively strained and fully relaxed GaAsBi compound, respectively. 
constant of $6.33 \AA$ was used [1]. The XRD curve of the as-grown GaAsBi was fitted yielding the GaAsBi composition of $x \sim 12 \%$ for the sample grown at $300^{\circ} \mathrm{C}$ temperature. On the other hand, the rocking curve scan of the reflex (see Fig. 2) obtained for GaAsBi with 7\% Bi (sample B770) and $3.3 \% \mathrm{Bi}$ (sample B771) layers grown at relatively higher temperatures of about 350 and $370^{\circ} \mathrm{C}$, respectively, demonstrated enhanced peak intensity and narrower full width at half maximum (FWHM) evidencing much higher crystalline quality. The double peak in Fig. 2(a) is attributed to two GaAsBi layers containing the same Bi content, but differing in compressive strain relaxation levels. Investigation of the $\mathrm{X}$-ray diffraction reciprocal space mapping of reflexes (004) and using grazing incident angle geometry for (224), presented for sample B266 on Fig. 1(b), revealed that thick epitaxial GaAsBi layers are partially relaxed.
In the case of sample B266 the relaxation reaches $50.7 \%$. The evaluated relaxation level for thick GaAsBi layers grown in the whole range of temperatures varied from $40 \%$ in GaAsBi with $3.3 \%$ Bi to $51 \%$ in layers with $12 \% \mathrm{Bi}$.

Figure 3 shows the atomic force microscopy (AFM) images of two investigated GaAsBi samples grown at different substrate temperatures, $300^{\circ} \mathrm{C}((\mathrm{a})$, sample $\mathrm{B} 266)$ and $350^{\circ} \mathrm{C}((\mathrm{b})$, sample $\mathrm{B} 770)$. The image taken on the sample GaAsBi with $7 \%$ Bi reveals a quite smooth morphology. One can point out that the surfaces of both samples are free from the metallic droplets. However, the surface quality is critically sensitive to the layer growth conditions, especially to the substrate temperature, the BEP ratio of $\mathrm{As}_{2}$ and $\mathrm{Ga}$, and the growth rate. It is clearly seen from the images that the surface roughness of the thick GaAsBi layer deposited at $300^{\circ} \mathrm{C}$ with a higher growth
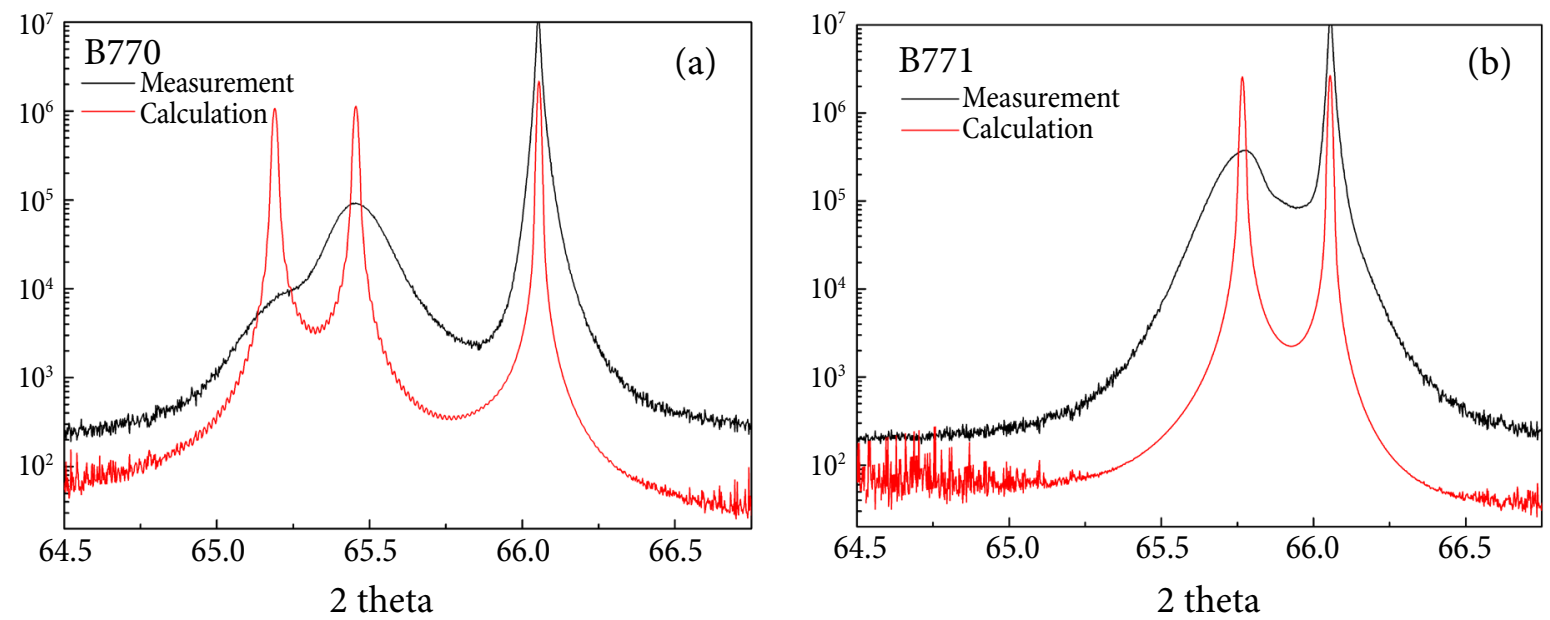

Fig. 2. HR-XRD $\omega-2 \Theta$ scan of the (004)-plane reflex measured for GaAsBi layers containing $7 \% \mathrm{Bi}$ ((a), sample $\mathrm{B} 770)$ and $3.3 \% \mathrm{Bi}((\mathrm{b})$, sample $\mathrm{B} 771)$ grown at temperatures of about $350^{\circ} \mathrm{C}$ and $370^{\circ} \mathrm{C}$, respectively.
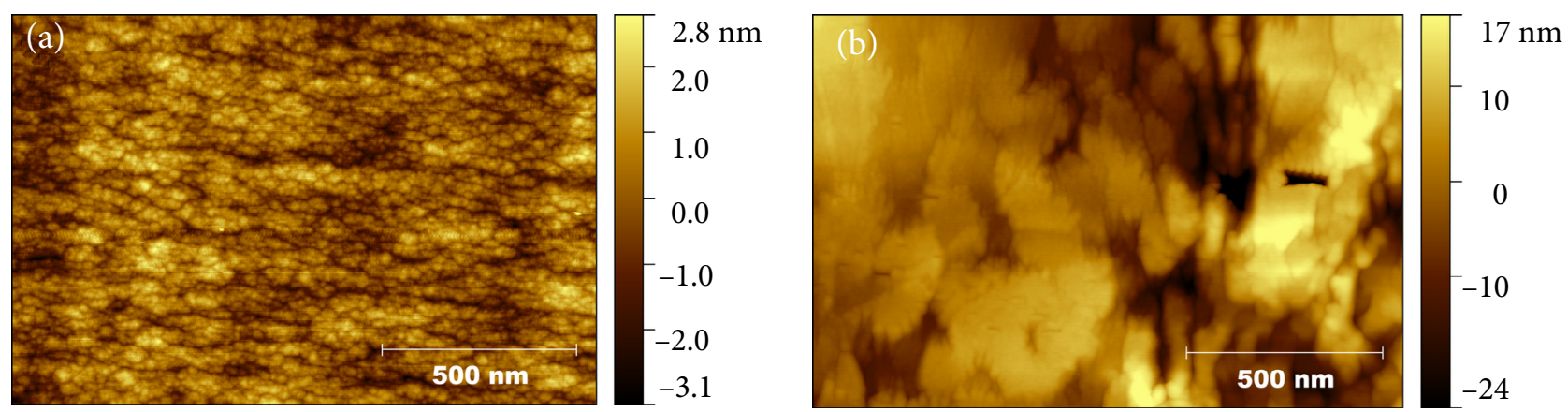

Fig. 3. AFM images of two investigated GaAsBi samples grown by molecular beam epitaxy at $300^{\circ} \mathrm{C}$ (a) and $350^{\circ} \mathrm{C}$ (b). $1.5 \times 1.5 \mu \mathrm{m}^{2}$ images are taken on the sample GaAsBi with $12 \% \mathrm{Bi}$ (a) and GaAsBi with $7 \% \mathrm{Bi}(\mathrm{b}$ ). The scale bar represents the peak-to-peak (from minimum to maximum) value. 
rate and lower $\mathrm{BEP} \mathrm{As} / \mathrm{Ga}$ is almost by one order higher in comparison to the bismide layer grown at $350^{\circ} \mathrm{C}$ substrate temperature.

\section{Optical characteristics}

Several experimental techniques were employed for determination of the electron energy band structure parameters of the investigated GaAsBi layers. Optical absorption was used for measurement of the energy bandgaps, whereas the energy position of subsidiary, high effective mass conduction band valleys was found by terahertz emission spectroscopy [11]. Figure 4 shows the optical absorption spectra measured on three GaAsBi layers with a different Bi content. For direct bandgap semiconductors, the dependence of the squared absorption coefficient on the photon energy gives a linear plot intersecting with the $x$ axis at the energy bandgap value. In the case of our measurements on $1.5 \mu \mathrm{m}$ thick GaAsBi layers, such a procedure could be applied successfully only for the samples with $x<10 \% \mathrm{Bi}$ (see, e.g. graphs for layers B770 and B771 in Fig. 4). For larger Bi contents, no unambiguous intersection with the $x$ axis was visible on the $(\alpha d)^{2}$ spectral dependences, possibly because of a limited sensitivity of the Ge detector in a long wavelength range.

The $\varepsilon_{\Gamma X}$ is the energy position of subsidiary conduction band valleys in the GaAsBi material. The values for GaAsBi with a different Bi content were found from the $\mathrm{THz}$ excitation spectroscopy - an experiment where the amplitude of a $\mathrm{THz}$ pulse emitted by the surface of a semiconductor illuminated by a femtosecond laser pulse is measured as a function of the laser photon energy [12]. The excess energy of electrons excited in the conduction band increases with increasing the photon energy, thus leading to an enhancement of photoelectron velocity and a larger spatial separation between the electrons and holes. Dynamic polarization caused by this separation leads to the emission of the THz pulse; its amplitude increases with growing photon energy as long as the electron excess energy becomes larger than $\varepsilon_{\Gamma X}$ and intense inter-valley scattering begins to impede the electron movement. Therefore, $\mathrm{THz}$ excitation spectra measured on GaAsBi layers with various $\mathrm{Bi}$ composition can be used for determining the inter-valley energy separation in the conduction band. These spectra were measured by using 140 to $160 \mathrm{fs}$ duration, $200 \mathrm{kHz}$ repetition rate optical pulses generated by an amplified laser/optical parametric amplifier (OPA) system (PHAROS/ ORPHEUS from Light Conversion Ltd.). The laser wavelength was tuneable in the range from 640 to $2600 \mathrm{~nm}$. Clear maxima of the excited $\mathrm{THz}$ pulse spectra have been observed on the samples with a relatively low Bi content. Only a monotonous increase of the $\mathrm{THz}$ pulse amplitude was evidenced for the layers with the largest $\mathrm{Bi}$ content $(>10 \% \mathrm{Bi})$, moreover, the $\mathrm{THz}$ emission efficiency in these layers is much lower than in the layers containing less bismuth. Hall effect measurements (not presented in this paper) show a significant increase of the hole concentration (up to $10^{17} \mathrm{~cm}^{-3}$ and more)

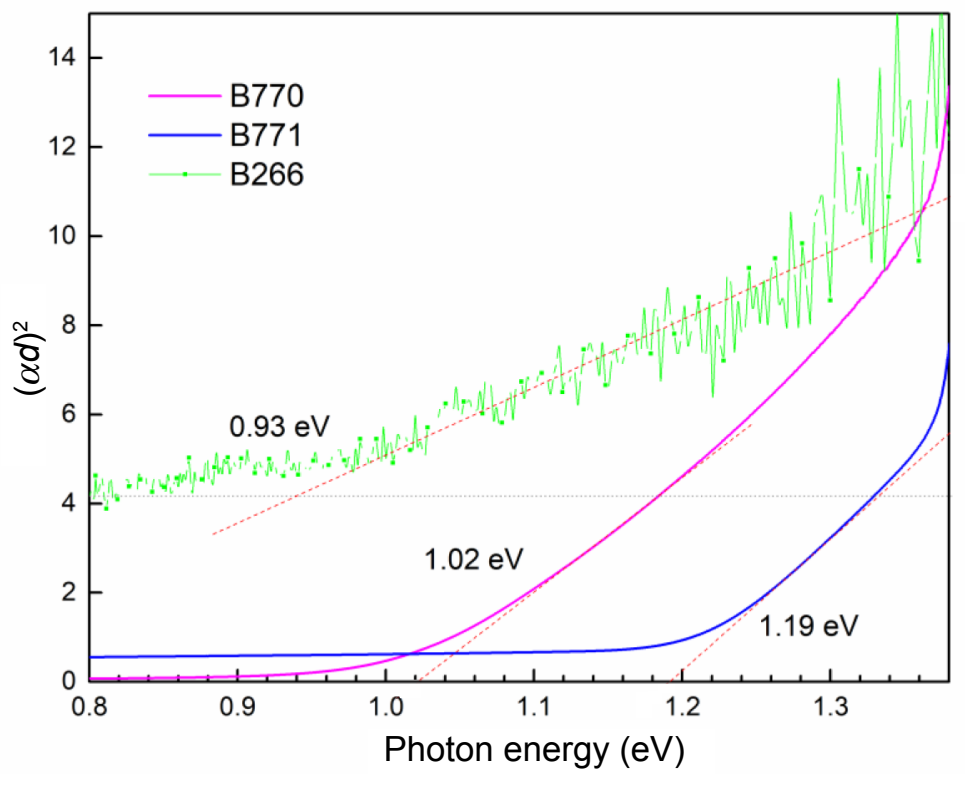

Fig. 4. Square of the absorption coefficient multiplied by the thickness of GaAsBi layers containing different $\mathrm{Bi}$ content as a function of photon energy measured at room temperature. 
with a simultaneous reduction of their mobility, therefore, the failure to observe inter-valley scattering from the $\mathrm{THz}$ excitation spectroscopy experiment on these layers does not necessarily indicate the direct-indirect bandgap transition at a large $\mathrm{Bi}$ content. The energy position of subsidiary conduction band valleys as well as the values of the energy bandgap versus the $\mathrm{Bi}$ content in GaAsBi layers is summarized in Fig. 5 .

\section{Electron dynamics}

The electron trapping time is a critical parameter for materials used as substrates of $\mathrm{THz}$ photoconductive components. Carrier dynamics in the GaAsBi layers was investigated by the optical pump-THz probe technique with a mode-locked Yb:KGW laser (1030 nm wavelength, pulse duration of $70 \mathrm{fs}$, and pulse repetition rate of $76 \mathrm{MHz}$ ) and photoconductive antennas manufactured from $\mathrm{GaAs}_{1-x} \mathrm{Bi}_{x}$ that were used for $\mathrm{THz}$ pulse generation and detection. The dependence of the transient $\mathrm{THz}$ signal at its maximum amplitude was measured at different delays of the optical pump pulse with a temporal resolution of $\sim 800 \mathrm{fs}$. At time delays where optical-pump and $\mathrm{THz}$-probe pulses do not overlap, optically induced changes in the probe pulse amplitude will depend solely on sample's conductivity due to photoexcited current carriers [14, 15]. When the thickness of the conducting film is sufficiently smaller than the wave- length of $\mathrm{THz}$ radiation, this time-dependent change in the conductivity $\Delta \sigma(t)$ can be evaluated from the change in the $\mathrm{THz}$ electrical field amplitude $\Delta E(t)$ normalized to its incident value $E_{0}$ using the formula [14]

$$
\sigma(t)=e N(t) \mu(t)=\frac{1+n}{Z_{0} d}\left[\frac{1}{1+\Delta E(t) / E_{0}}-1\right]
$$

where $N$ is the electron density, $\mu$ is the mobility, $n$ is the refractive index of the substrate, $d$ is the optical absorption length, and $Z_{0}$ is the freespace impedance. When $\Delta E(t) / E_{0} \ll 1$, relation (1) becomes linear and the conductivity dynamics can be directly determined from the measurements of the optically excited $\mathrm{THz}$ pulse transmittance transients. As the electrons are more mobile than the holes, optically induced changes of $\mathrm{THz}$ transmittance are usually interpreted in terms of the electron characteristics. The electron trapping time is found from the exponential decay of the $\mathrm{THz}$ transient, whereas the amplitude of this transient at its maximum is approximately proportional to the electron mobility.

Typical results of the optical pump-THz probe measurement of GaAsBi (sample B266) are presented in Fig. 6. The carrier lifetime was extracted from the fitted curve (see the equation in the inset). It must be noted that electron trapping times $\tau$ were the shortest for GaAsBi grown at a lower temperature of about $300^{\circ} \mathrm{C}, \tau$ of $\mathrm{GaAsBi}$

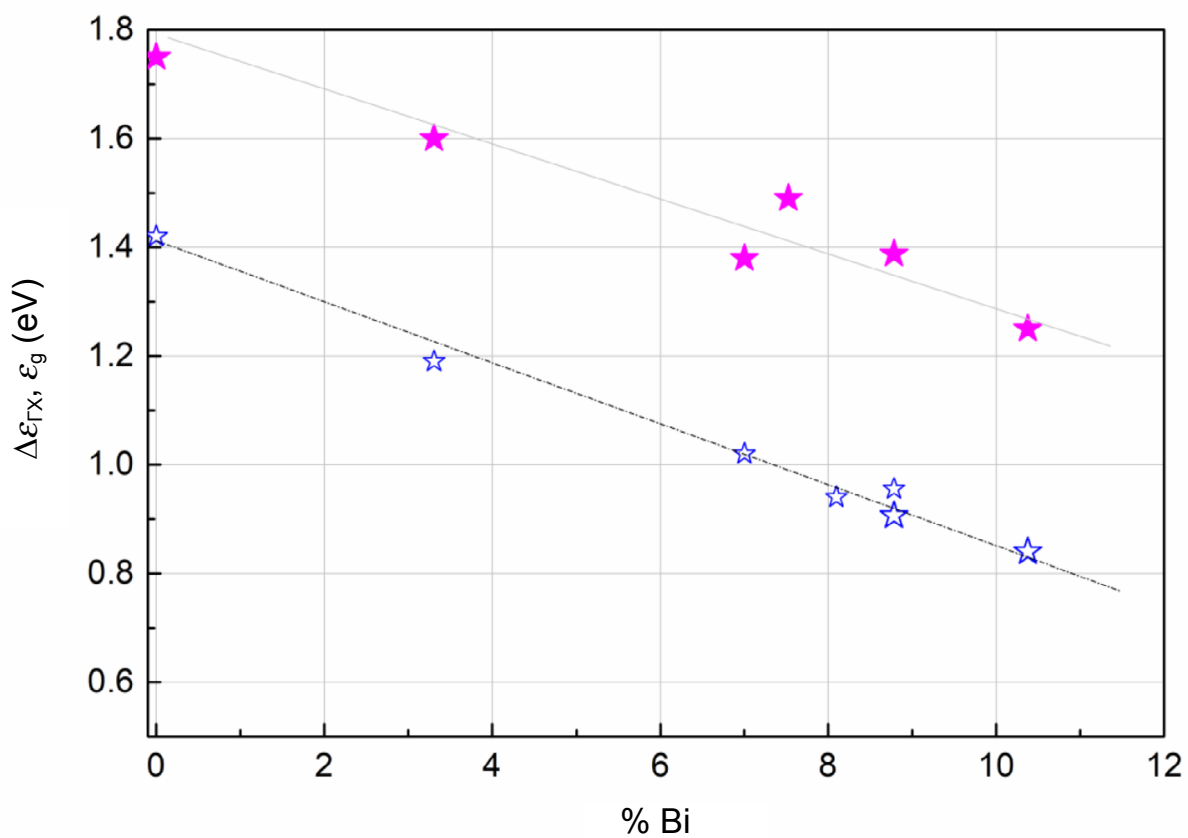

Fig. 5. The energy position of subsidiary conduction band valleys $\varepsilon_{\Gamma X}$ shown by magenta (online) filled star symbols and energy bandgap $\varepsilon_{\mathrm{g}}$ marked by the dependence of blue (online) open star symbols on the Bi content in thick GaAsBi layers. 


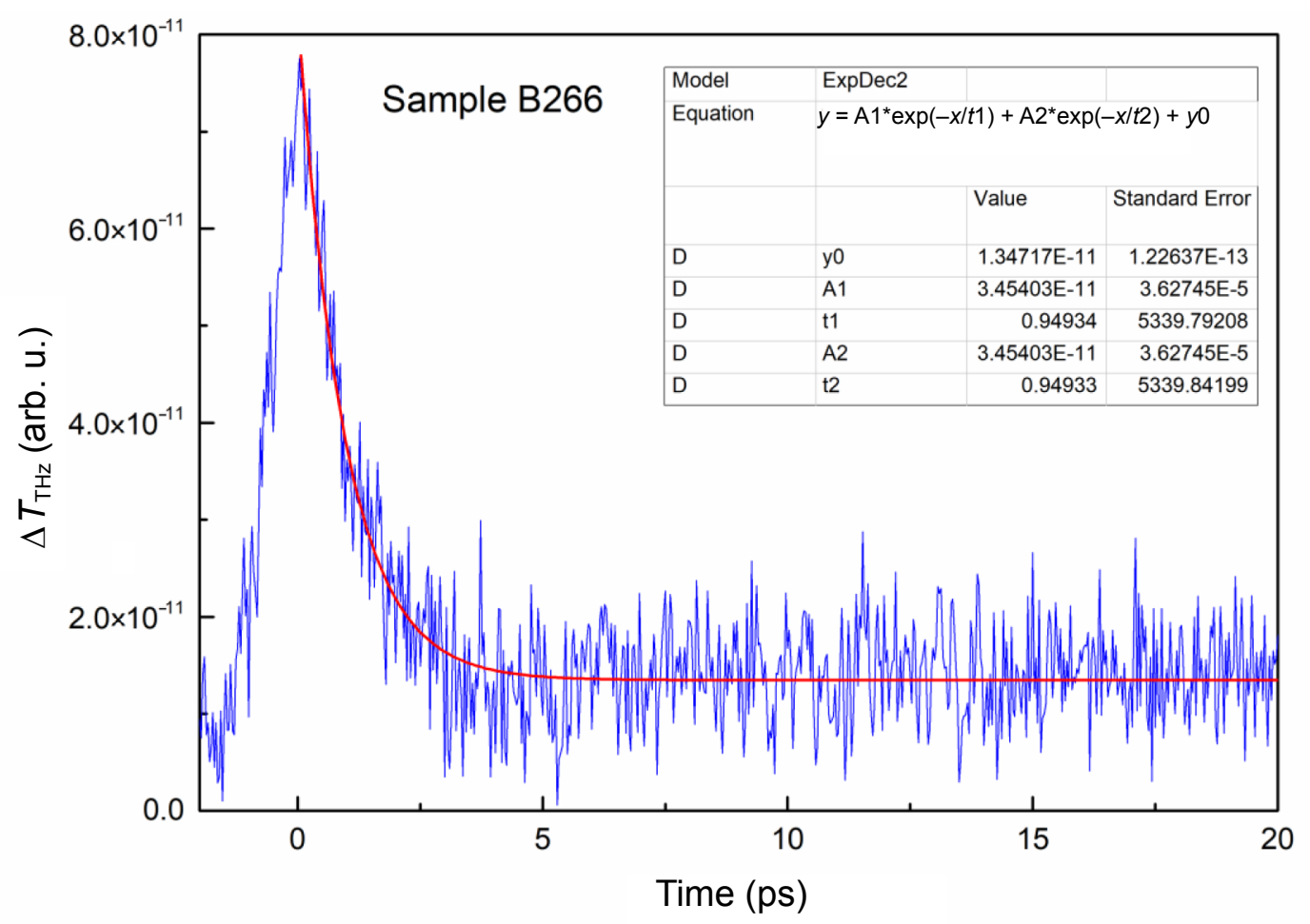

Fig. 6. The optical pump-THz probe carrier dynamic obtained for low-temperature-grown GaAsBi with $12 \%$ of $\mathrm{Bi}$. The blue (online) curve presents the data of measurement; the red (online) curve was calculated using the equation shown in the inset of the figure. The carrier lifetime was extracted as the parameter from the fitting curve.

with the largest $12 \% \mathrm{Bi}$ content was $0.95 \mathrm{ps}$, which is close to the temporal resolution of the measurement. The lifetime values obtained for thick $\mathrm{GaAsBi}$ layers grown at higher than $350^{\circ} \mathrm{C}$ temperatures reached tens of picoseconds (see Table 1). The clear correlation between the trapping time and the amplitude of the optically induced $\mathrm{THz}$ absorbance, related to the electron mobility (not presented in this paper), evidences that both carrier scattering and their mobility are affected by the same defects, whose density depends more on the layer growth conditions than on its composition.

\section{Conclusions}

A series of thick epitaxial GaAsBi layers were grown by molecular beam epitaxy on semi-insulating GaAs (100). The growth temperatures were kept in a range of $300-370^{\circ} \mathrm{C}$. The growth rate varied from 350 to $750 \mathrm{~nm} / \mathrm{h}$, and the thickness of GaAsBi layers was $1500 \mathrm{~nm}$. The Bi content in GaAsBi layers was evaluated from rocking curves measured on the (004) reflex and varied from 3.3 to $12 \%$. The thick GaAsBi layers grown at higher than $350^{\circ} \mathrm{C}$ temperatures demonstrated a higher crystalline quality. The carrier dynamics measurements performed using an optical pump- $\mathrm{THz}$ probe method showed that the lifetimes of GaAsBi layers grown at lower temperatures varied from 1 to $3 \mathrm{ps,}$ while the bismides deposited at higher than $350^{\circ} \mathrm{C}$ temperatures exhibited longer lifetimes of about few tens of picoseconds. These achievements display the prospective applications of thick epitaxial $\mathrm{GaAsBi}$ layers in photoconductive $\mathrm{THz}$ components, detectors and emitters.

\section{Acknowledgements}

This work was partially supported by the Research Council of Lithuania under Grant No. 09.3.3-LMTK-712-02-0149.

\section{References}

[1] A. Krotkus, Semiconductors for terahertz photonics applications, J. Phys. D 43(27), 273001 (2010), https://doi.org/10.1088/0022-3727/43/27/273001

[2] F.W. Smith, H.Q. Le, V. Diadiuk, M.A. Hollis, A.R. Calawa, S. Gupta, M. Frankel, D.R. Dykaar, 
G.A. Mourou, and T.Y. Hsiang, Picosecond GaAs-based photoconductive optoelectronic detectors, Appl. Phys. Lett. 54, 890 (1989), https:// doi.org/10.1063/1.100800

[3] A. Biciunas, J. Adamonis, and A. Krotkus, Terahertz time-domain-spectroscopy system using a 1 micron wavelength laser and photoconductive components made from low-temperature-grown GaAs, J. Infrared Millim. Terahertz Waves 33(2), 183-191 (2012), https://doi.org/10.1007/s10762011-9857-7

[4] K. Bertulis, A. Krotkus, G. Aleksejenko, V. Pacebutas, R. Adomavicius, G. Molis, and S. Marcinkevicius, GaBiAs: A material for optoelectronic terahertz devices, Appl. Phys. Lett. 88(20), 201112 (2006), https://doi.org/10.1063/1.2205180

[5] V. Pacebutas, K. Bertulis, G. Aleksejenko, and A. Krotkus, Molecular-beam-epitaxy grown GaBiAs for terahertz optoelectronic applications, J. Mater. Sci. Mater. Electron. 20, 363-366 (2009), https://doi.org/10.1007/s10854-008-9625-1

[6] D.G. Cooke, F.A. Hegmann, E.C. Young, and T. Tiedje, Electron mobility in dilute GaAs bismide and nitride alloys measured by time-resolved terahertz spectroscopy, Appl. Phys. Lett. 89(12), 122103 (2006), https://doi.org/10.1063/1.2349314

[7] B. Čechavicius, R. Adomavičius, A. Koroliov, and A. Krotkus, Thermal annealing effect on photoexcited carrier dynamics in $\mathrm{GaBi}_{x} \mathrm{As}_{1-x}$, Semicond. Sci. Technol. 26(8), 085033 (2011), https://doi.org/10.1088/0268-1242/26/8/085033

[8] V. Pacebutas, A. Biciunas, K. Bertulis, and A. Krotkus, Optoelectronic terahertz radiation system based on femtosecond $1 \mu \mathrm{m}$ laser pulses and GaBiAs detector, Electron. Lett. 44(19), 1154 (2008), https://doi.org/10.1049/el:20081630

[9] V. Pacebutas, A. Biciunas, S. Balakauskas, A. Krotkus, G. Andriukaitis, D. Lorenc, A. Pugzlys, and
A. Baltuska, Terahertz time-domain-spectroscopy system based on femtosecond Yb:fibre laser and $\mathrm{GaBiAs}$ photoconducting components, Appl. Phys. Lett. 97(3), 031111 (2010), https:// doi.org/10.1063/1.3458826

[10] R. Butkutè, V. Pačebutas, B. Čechavičius, R. Adomavičius, A. Koroliov, and A. Krotkus, Thermal annealing effect on the properties of GaBiAs, Phys. Status Solidi C 9, 1614 (2012), https://doi. org/10.1002/pssc.201100700

[11]S. Tixier, M. Adamcyk, T. Tiedje, S. Francoeur, A. Mascarenhas, P. Wei, and F. Schiettekatte, Molecular beam epitaxy growth of $\mathrm{GaAs}_{1-x} \mathrm{Bi}_{v^{\prime}}$, Appl. Phys. Lett. 82, 2245 (2003), https://doi. org/10.1063/1.1565499

[12]A. Arlauskas and A. Krotkus, THz excitation spectra of AIIIBV semiconductors, Semicond. Sci. Technol. 27, 115015 (2012), https://doi. org/10.1088/0268-1242/27/11/115015

[13]V. Pačebutas, K. Bertulis, L. Dapkus, G. Aleksejenko, A. Krotkus, K.M. Yu, and W. Walukiewicz, Characterization of low-temperature molecular-beam-epitaxy grown GaBiAs layers, Semicond. Sci. Technol. 22, 819 (2007), https:// doi.org/10.1088/0268-1242/22/7/026

[14]M.C. Beard, G.M. Turner, and C.A. Schmuttenmaer, Transient photoconductivity in GaAs as measured by time-resolved terahertz spectroscopy, Phys. Rev. B 62, 15764 (2000), https://doi. org/10.1103/PhysRevB.62.15764

[15]K.P.H. Lui and F.A. Hegmann, Ultrafast carrier relaxation in radiation-damaged silicon on sapphire studied by optical-pump-terahertzprobe experiments, Appl. Phys. Lett. 78, 3478 (2001), https://doi.org/10.1063/1.1375841 


\title{
STORIEJI EPITAKSINIAI GaAsBi SLUOKSNIAI TERAHERCINIAMS PRIETAISAMS: AUGINIMO SĄLYGŲ SVARBA SLUOKSNIŲ SAVYBĖMS
}

\author{
S. Stanionyte ${ }^{\text {a }}$, A. Vailionis ${ }^{\text {b }}$, V. Bukauskas ${ }^{\text {a }}$, S. Tumènas ${ }^{\text {a }}$, A. Bičiūnas ${ }^{\text {a }}$, A. Arlauskas ${ }^{\text {a }}$, R. Butkutè ${ }^{\text {a }}$, \\ A. Krotkus a \\ ${ }^{\text {a }}$ Fiziniu ir technologijos mokslu centro Optoelektronikos skyrius, Vilnius, Lietuva \\ ${ }^{\mathrm{b}}$ Geballe pažangių medžiagų laboratorija, Stanfordo universitas, JAV
}

\begin{abstract}
Santrauka
1,5 $\mu \mathrm{m}$ storio epitaksiniai GaAsBi sluoksniai buvo auginti molekulių pluoštelio epitaksijos būdu ant puslaidininkių GaAs (100) padèklų esant $300-370^{\circ} \mathrm{C}$ temperatūroms. Technologinių parametrų optimizavimas buvo vykdomas turint tikslą storus GaAsBi sluoksnius taikyti teraherciniuose prietaisuose - detektoriuose ir emiteriuose. Atlikti kompleksiniai kristalinès sandaros, paviršiaus morfologijos, optinių savybių ir krūvininkų gyvavimo trukmių tyrimai atskleidè, kad auginant sluoksnius šiame temperatūrų intervale GaAs gardeleje
\end{abstract}

galima pakeisti nuo 3,3 iki 12,0\% arseno atomų bismuto atomais. Ivedus iki 12,0 \% bismuto draustinių energijų tarpas susiaurejo nuo 1,42 iki 0,93 eV. Žemose temperatūrose $\left(300^{\circ} \mathrm{C}\right)$ užauginti $\mathrm{GaAsBi}$ sluoksniai pasižymèjo 1-3 ps krūvininkų gyvavimo trukmèmis, o bismidai, auginti $350^{\circ} \mathrm{C}$ ir aukštesnèse temperatūrose, buvo tvarkingesnès kristalinès sandaros, jų gyvavimo laikas siekè net dešimtis pikosekundžių. Pasiekti rezultatai rodo, kad storieji GaAsBi sluoksniai gali būti naudojami terahercinių detektorių ir emiterių gamyboje. 